\title{
What's in a Name? On the Titles of Early Modern Narratives, in Particular Those of the Spanish libros de caballerías
}

\begin{abstract}
Book titles in Early Modern narratives are a neglected field of study that can help us understand the formation of narrative genres. Examining the corpus of Spanish chivalric romances, this article shows how specific paratextual strategies developed by printers in the sixteenth century for the libros de caballerías have led to a generally homogeneous view of the genre. A diachronic reconstruction, however, suggests that the way the romances were titled and designed needs to be contrasted with the books' actual contents and narrative techniques. In this way, different sub-categories might be distinguished in part by their respective titles. The last section discusses an important alternative title in the transmission of Don Quixote.
\end{abstract}

Die Titel frühneuzeitlicher Erzählliteratur sind ein vernachlässigter Forschungsbereich, helfen uns jedoch, die Entwicklung von Erzählgattungen nachzuvollziehen. Eine Untersuchung des Textkorpus der Kastilischen Ritterromane zeigt, dass für die libros de caballerías von Druckern des 16. Jh. spezifische Strategien paratextueller Rahmung entwickelt wurden, die stark zur Auffassung beitrugen, es handle sich um eine homogene Gattung. Eine diachrone Rekonstruktion suggeriert jedoch, dass die Titel und visuelle Gestaltung der Romane gesondert von den inhaltlichen und erzähltechnischen Eigenschaften betrachtet werden müssen. Auf diese Weise können nicht zuletzt mehrere Untergattungen unterschieden werden. Das letzte Kapitel behandelt einen wichtigen alternativen Titel in der Überlieferung des Don Quijote.

\section{Introduction}

In contrast to the rather superficial treatment of the Spanish libros de caballerias by former generations of Hispanists, who valued them mainly as unworthy precursors to Don Quixote, the last 25 to 30 years have seen a marked increase in dedicated studies of the genre and of particular texts. Nevertheless, various fundamental problems still remain unsolved. They stem in part from the long scholarly tradition of regarding the libros de caballerías as a homogeneous group of texts, a point of view that derives among other things from specific paratextual strategies developed by printers in the course of the sixteenth century.

Daniel Syrovy, University of Vienna

¿ Open Access. (C 2019 Daniel Syrovy, published by De Gruyter. (cc) BY-NC-ND This work is licensed under a Creative Commons Attribution-NonCommercial-NoDerivatives 4.0 International License.

https://doi.org/10.1515/9783110563016-013 
Confronted with a corpus of approximately 220 extant editions of 67 romances (plus 20 unique manuscripts), ${ }^{1}$ both differences and similarities between various editions (and their editorial presentation) can be highlighted, depending on the line of reasoning. In order to properly situate the Spanish libros de caballerías in the context of Early Modern narrative, as part of the "history of the novel' and not least as a specific genre, a differentiated view of the romances is necessary. Distinguishing between the narrative and thematic content of particular romances on the one hand and the editorial history of the genre as a whole on the other hand, is one of the more important steps in this direction. For both aspects, much research is still to be done. Problematically, the way differences between the romances were homogenized even in the sixteenth century (scholars have called this the editorial genre or "género editorial" of the romances), can often obscure our view. This article aims to show how the title pages and title conventions of the romances contribute to these difficulties.

\section{The Problem of Titles}

Titles, despite being one of the most salient features of a literary text, have rarely been studied systematically. Franco Moretti's chapter in Distant Reading is an instructive example of how to look at the problem, comparing the semantics of titles of seventhousand eighteenth- and nineteenth-century British novels. ${ }^{2}$ What has been written on the subject confirms that the phrasing of titles and the formation of genres are not independent from each other, which is why the lack of studies must be considered especially problematic for the fifteenth and sixteenth centuries. Looking at narrative forms and genres during the period of early print, it is not hard to observe tendencies towards genre-

1 The relevant bibliographies are Daniel Eisenberg and María Carmen Marín Pina, Bibliografia de los libros de caballerías castellanos. Zaragoza 2000 (digital edition: http://www.cervantesvir tual.com/obra/bibliografia-de-los-libros-de-caballeria-castellanos/; accessed 25 May 2017) and the Appendix included in José Manuel Lucía Megías and Emilio José Sales Dasí, Libros de caballerías castellanos (siglos XVI-XVII). Madrid 2008, p. 295-308. Since several of the catalogued editions are lost or doubtful and others deliberately excluded, it is not easy to state precise numbers. Much of the information in Alexander S. Wilkinson (ed.), Iberian Books. Leiden, Boston 2010 is not very reliable. On the question of the manuscript diffusion of the romances, see Manuel Sánchez Mariana, 'La novela en manuscrito en los Siglos de Oro'. In: Imprenta, libros y lectura en la España del Quijote. Ed. by José Manuel Lucía Megías. Madrid 2006, p. 119-138.

2 Franco Moretti, Distant Reading. London, New York 2013, p. 179-210. Some observations on the titles of Spanish narratives in the 17th century, mainly concerning genre descriptors, can be found in Anne Cayuela, Le paratexte au siècle d'or. Prose romanesque, livres et lecteurs en 
specific titles. Titles in fact are often phrased in a way that copies a successful predecessor. For example, even though the 1482-1483 first edition of Boiardo's epic poem about Orlando is lost, its title is usually reconstructed as Libro de l'inamoramento de Orlando, modelled on the [Primo] libro del in amoramento de Carlo Ma[g]no (first printed in Venice, 1481; GW 12613). ${ }^{3}$ Today, however, the poem is known mainly as Orlando innamorato, due to Ludovico Ariosto's Orlando furioso (1516), formally a continuation of Boiardo's poem, which was so successful that it influenced the title form of the earlier text until today (Ariosto's title itself was modelled on Seneca's Hercules furens).

Similarly, Jorge de Montemayor's pastoral romance starts out as the pseudo-Latinate Los siete libros de la Diana in the early editions (Milan 1560?, Barcelona 1561, Lisbon 1565, ... ${ }^{4}$ ), following the structure of titles such as Metamorphoseon libri XV and Aeneidos libri XII. Later on, it changes to La Diana, definitively so after 1613 . This change may have been influenced by the shortening already present in the Segunda parte de la Diana (Venice 1568; USTC 337847), but it also coincides with a trend observable in other examples of the genre, a narrative style that after all started with Arcadia del Sannazaro (Naples 1504; USTC 991320). Examples include the Primera parte de la Galatea dividida en seys libros by Cervantes (Alcalá 1585; USTC 348149) reprinted in Paris in 1611 as Galatea dividida en seys libros and perhaps culminates with d'Urfé's L'Astrée (Paris 1607), of which two different 1607 editions exist that reflect the same change. $^{5}$

These examples may be anecdotal, but they point toward a major issue: There is little stability regarding the phrasing of titles in the early period of print. Titling as well as book design certainly play an important part in the formation and recognizability of genres, but the complex dynamics of stylistic influence as well as market considerations are far from being well understood. Moreover,

Espagne au XVII ${ }^{e}$ siècle. Genève 1996, p. 248-265. [For title-pages, see also the articles by Van Hemelryck and Delsaux, p. 189-237 and by Schaeps, p. 297-324 in the present volume.]

3 See Andrea Canova, 'Introduction'. In: Matteo Maria Boiardo, Orlando innamorato. L'inamoramento de Orlando. Ed. by Andrea Canova. Milano 2011, p. 5-65, here p. 10-12. For the early edition, see GW 04607.

4 USTC 337840, 340124, 337842, respectively.

5 Both editions are by Toussaint du Bray, Paris 1607. One states "L'ASTREE | DE MESSIRE HONORE DURFE [. . .]" (Ex. BNF, RES P-Y2-261); the other, likely the earlier one that still lacks the author's name, "LES | DOUZE LIVRES | D'ASTREE [...]” (Ex. BNF, Rothschild-V, 2.18). Judging by the critical on-line editions (http://astree.tufts.edu and http://www.astree.parissorbonne.fr/, accessed 25 May 2017), part of the foliation has changed as well. Yet the editions must have succeeded each other quickly. In both cases, the privilege is dated 18 August 1607 and is for "un livre intitulé L'Astrée". 
modern conventions further obscure particular traditions, something that is not only a problem with the Spanish chivalric romances but extends even to classical texts: The titles of Latin editions of Valerius Maximus from the first half of the sixteenth century, for example, are as diverse as Prisci exempla, Facta et dicta memorabilia and Facinora memorabilia. ${ }^{6}$ The advantages of short titles as generally used today are therefore counterbalanced by a great loss of detail. It may be a type of problem that has less to do with establishing an 'ideal text' than with reconstructing processes of reception, but the distinction is not quite as clear-cut. With respect to medieval manuscripts, Richard Sharpe argues that our knowledge of certain texts is limited precisely by the inability to correctly identify certain branches of their transmission, among other reasons, because the catalogues collecting the information traditionally tend towards "conservatism or convenience rather than [...] evidence". ${ }^{7}$ One of Sharpe's examples is a list of 53 known manuscripts of Isidore's Sententiae. Only eight of them contain the familiar title-word, while almost forty are a variation of De summo bono. Others include De diuersis uirtutibus, De lapsis and combinations thereof (e.g. "de summo bono et diuersis uirtutibus"). ${ }^{8}$

While this may be a challenge for bibliography, book history and literary history, it is of crucial importance for understanding not only book transmission, but also other kinds of historical context. The information allows us to reconstruct processes of influence or developments in editing, but since a title has a major influence on a reader's understanding of a text, it also indicates the practical use of books as well as the public's expectations. Unfortunately, tools such as the otherwise invaluable Universal Short Title Catalogue (USTC), as well as most modern editions (including critical ones) are of little help because they mainly use normalized titles in the first place. Therefore, it is essential to go back to the original editions (or, increasingly, to digitizations) to record faithfully what the title-pages state exactly and what they look like. Additionally, the relationship between titles as given on title-pages and, on the

6 The full titles are: Valerii Maximi Priscorum exemplorum libri nouem: diligenti castigatione emendati: aptissimisque figuris exculti (Venetia: Zanis 1508; USTC 861756); Valerij Maximi Romani generis viri facta et dicta memorabilia Jterum recognita et accuratiore castigatione impressa q[uae] scriptor ille illustris Cesari Claudio Tyberio neroni dedicauit... (Lipsia: Landsberg 1509; USTC 700294); Valerij Maximi Ciuis Romani de factis ac dictis memorabilib[us] Exemplor [um] Libri nouem: tum [pro]pter stili maturitatem: tum vero propter vite instructionem vtilissimi. (Lipsia: Lotter 1514; USTC 697004); Valerii Max. Libri 9. in quibus, quod philosophi alijque scriptores praeceptionibus, hic uir prudens \& sapiens facinorum memorabilium exemplis tradit. (Basilea: Petri 1540; USTC 700274).

7 Richard Sharpe, Titulus. Identifying Medieval Latin Texts. Turnhout 2006, p. 27.

8 Sharpe (see note 7), p. 91-93. 
other hand, in incipits, colophons, privileges, as well as in the form of references in other texts, might throw even more light on these issues. ${ }^{9}$

\section{The Titles of Spanish Chivalric Romances}

The way the libros de caballerias were perceived as a genre in the sixteenth century, and often still are today, may serve as an example for why these methodological approaches have practical consequences. A question that is especially vexing in this respect is that of short titles. For practical reasons, all modern scholars use them to designate the Spanish chivalric romances, including in bibliographies and in the series of new editions, the Libros de Rocinante, published by the Centro de Estudios Cervantinos in Alcalá de Henares. Short titles are, of course, a quick and handy reference, even though they deviate from the evidence of the books themselves. Moreover, the habit is anything but recent. Short titles have been in use from antiquity on (on the outside of scrolls ${ }^{10}$ ) and contemporaries of the libros de caballerias unsurprisingly used them as well. Elisabetta Sarmati collects 93 fifteenth- and sixteenth-century witnesses commenting on the genre and all of them use short forms (except 33 who do not mention specific titles at all). These forms are indistinguishable from the heroes of the books: Amadis, Primaleón, Don Clarián. ${ }^{11}$ It may be significant that only twelve of the commentators have a generally positive view of the phenomenon of libros de caballerías, but the titles as such do not appear plainly dismissive. By contrast, as many as sixteen writers employ adjectival or plural forms of the names, a negative strategy that Sarmati herself identifies as a "topos of abundance". There is talk of Amadises and Palmerines and poisonous "cavallerías amadísicas y espla[n]diánicas". ${ }^{12}$ In addition, this sort of criticism often

9 Cf. Ursula Rautenberg, 'Die Entstehung und Entwicklung des Buchtitelblatts in der Inkunabelzeit'. In: Archiv für Geschichte des Buchwesens 62 (2008), p. 1-105 and especially her remarks on title-pages and colophons, p. 16.

10 See Revilo P. Oliver, 'The First Medicean MS of Tacitus and the Titulature of Ancient Books'. In: Transactions and Proceedings of the American Philological Association 82 (1951), p. 232-261, p. 243.

11 Elisabetta Sarmati, Le critiche ai libri di cavalleria nel cinquecento spagnolo (con uno sguardo sul seicento). Un'analisi testuale. Pisa 1996, p. 115-179.

12 Sarmati's analysis of "Il tópos dell'abbondanza", Le critiche (see note 11), p. 54-56. The observation about the number of positive texts is her own and can be found on p. 61. The last quotation is from Alejo Venegas, introducing Alvar Gómez's Theológica descripción de los misterios sagrados (originally Toledo 1541), in Sarmati’s transcription, text no. 14, p. 131. 
concerns all popular fiction and some of the lists include titles like La Celestina or La Diana (also at times in plural forms) that are not part of the corpus of chivalric texts. This suggests that certain expectations of homogeneity and even interchangeability among the romances may have been related to, or underscored by, titling habits.

This notion is confirmed by one of the most extensive commentaries on the genre, Don Quixote, specifically chapter six of the first part, in which the curate sorts out the hidalgo's library. All but two of the titles mentioned are given in short form. Cervantes does emphasize differences in quality, however, and the two exceptions are also the most highly esteemed: "Los cuatro de Amadís de Gaula" (a reference to the original volume by Garci Rodríguez de Montalvo containing books one through four) and "Historia del famoso caballero Tirante el Blanco". ${ }^{13}$ The latter, interestingly, does not correspond to the actual book's title: Los cinco libros d[e]l efforçado \& inuencible cauallero Tirante el blanco de roca salada: Cauallero dela Garrotera [...]. Only the colophon, in fact, states "famoso \& inuencible" (fol. 288r; Valladolid 1511; USTC 347631). The evidence, therefore, remains ambivalent. In addition, Don Quixote treats some of the romances in an anthropomorphized manner. In fact, modern editions generally miss a fine point of the famous chapter, when Cervantes's phrase "las Sergas de Esplandián, hijo legítimo de Amadís de Gaula" [sic] is not set recte, like it is in all the early editions. ${ }^{14}$ Since the character Esplandian is the son of the knight Amadís, the statement is ambiguous: It can mean either that the character is the son of the other (parsing it as "las Sergas de [Esplandian, [[ hijo legítimo...]]") or that one book is the 'son' of the other (but then, surely, Amadis de Gaula is understood as a title as well, i.e. should be set in italics). This is not to say that every metonymic use of titles has such implications, ${ }^{15}$ but in Don Quixote the effect is clearly intentional. Overall, short titles for the romances are commonly used, then, and this even extends to some of the title-pages, as we will see.

13 In Miguel de Cervantes, El Ingenioso Hidalgo Don Quijote de la Mancha. Ed. by John Jay Allen. Madrid 2001, Amadís is called "el mejor de todos los libros que de este género se han compuesto" (p. 130) and Tirante is "un tesoro de contento y una mina de pasatiempos" (p. 134).

14 Madrid 1605 (2), Lisbon 1605 (2), Valencia 1605, Brussels 1607, Madrid 1608, Milan 1610, Brussels 1611, Brussels 1617.

15 Compare the case of La vida de Lazarillo de Tormes (the earliest editions are from 1554 in Antwerp, Burgos, Alcalá; USTC 440153, 351133, 343114), which becomes La segunda parte de Lazarillo de Tormes (Antwerp 1555; USTC 440363); modern editions, in fact, avoid this construction (paralleled by the Segunda parte de la Diana, quoted above) either by calling the book Segunda parte del Lazarillo de Tormes (e.g. ed. Alfredo Rodriguez López-Vázquez. Madrid 2014; my emphasis), or by supplying de la vida de. 


\section{The Conservative Design of the libros de caballerías and its Development}

Before looking more closely at the usage of short titles (or what may be taken for such) on the actual title-pages of some sixteenth-century editions of the libros de caballerias, a few words need to be said about the development of the chivalric title-pages in general. As already indicated, scholars have been talking about an editorial genre ("género editorial") in this respect, meaning that there had been a kind of 'standard design' of the chivalric romances for a long period of time. Influenced by the huge success of some of the early volumes, above all Amadis de Gaula, which dates from the first years of the sixteenth century, the title-pages of the romances in fact were strikingly conservative: The long titles were set in gothic type and usually printed with red and black ink. Most titlepages featured a large woodcut that covered the top half of the page, generally depicting a scene with a knight on horseback, and were often surrounded by a decorative border. ${ }^{16}$

The image of the knight was obviously intended to illustrate a particular text, but the high expenses connected with producing new woodcuts often led to their repeated use for different romances. This in turn strengthened the visual coherence of individual cycles and the whole genre, because the books resembled one another even more closely. Yet, perhaps out of a perceived shortcoming, in many cases the printers apparently tried to emphasize the informative character of the woodcuts by attaching the names of the knights to the images. Technically, there are at least four ways to accomplish this goal: In the first case, the woodcut itself includes the knight's name, most commonly on a banner. This was sometimes done by way of a separate piece superimposed on the image of the knight. ${ }^{17}$ Another method has the name printed with type inside the empty

16 Knights are, however, not the only subject of the woodcuts. There are also war scenes, sieges, heraldic motifs and sometimes religious or courtly scenes. This typology is taken in a simplified form from José Manuel Lucía Megías, 'Imprenta y lengua literaria en los Siglos de Oro: el caso de los libros de caballerías castellanos.' In: Edad de Oro 23 (2004), p. 199-229, here p. 208. A more extensive study of the design features of the whole corpus can be found in José Manuel Lucía Megías, Imprenta y libros de caballerías. Madrid 2000, p. 140-324. [For oldstyle title-pages, see also the article by Schaeps, p. 321-323, in the present volume.]

17 Beginning with the Amadís of 1508 (Zaragoza: Coci; USTC 342622) we find a handful of such cases, generally before 1550, for instance Las Sergas de Esplandián (Burgos: Juan de Junta 1526; USTC 348400) (see Fig. 1), or Clarian de Landanís (Sevilla: Jacobo \& Juan Cromberger 1527; USTC 338312). Belianís de Grecia (Burgos: Martín Muñoz 1547; USTC 336254) looks as if the knight and his name were on the same woodcut. 
space of the image, allowing for the woodcut's re-use while still creating the impression that the name belonged to the illustration. ${ }^{18}$ In a third variation, an empty banner in the woodcut image is filled with type printing. This can be found on the title-page of a 1566 Primaleón (Lisboa: Manuel João; USTC 343200) and a much later book very closely modelled on it, Choronica del mvy valiente [...] Amadis de Grecia (Lisboa: Lopes 1596; USTC 342631; see Fig. 3). ${ }^{19}$ The last option, to which we will return, is to print a knight's name in type above the woodcut, just outside the frame (see Fig. 5).

Sometimes, the reuse of woodcuts also clarifies processes of transmission. A very interesting example comes from the printing house of the Crombergers. ${ }^{20}$ One particular woodcut is first preserved on the title-page of the Historia del caballero Cifar (Sevilla: Jacobo Cromberger, 1512; USTC 337405). Since the Cifar is not properly a libro de caballerías, it is surprising that a more or less faithful copy of the image is used by Antonio de Salamanca in Rome for the title-page of his Amadís of 1519 (USTC 802205; see Fig. 6), where it is also repeated three more times at the start of the individual books within the volume. By itself, the Cifar a text from the 1300s that Cromberger edited in order to cash in on the new fashion of chivalric romances ${ }^{21}$ and apparently no great success, as there are no reprints or further editions - seems unlikely to have influenced the design of an edition of Amadís. Yet, it is well known that in the course of three generations, the Crombergers constantly reused woodcuts. ${ }^{22}$ The image in question, too, is still used 28 years after the Cifar on the title-page of an edition of Primaleón (Sevilla:

18 For instance, Las Historias del muy noble [... ] cauallero don Claria[n] de landanis (Toledo: Juan de Villaquiran, 1518; USTC 344400), or Los quatro libros del muy noble [. . . Felix magno (Sevilla: Trujillo 1549; USTC 342952; see Fig. 2). El octavo libro de Amadis (Sevilla: Jacobo \& Juan Cromberger 1526; USTC 337574), includes six small woodcuts of crowned king/knight figures with their respective names.

19 In the case of Silves de la Selva (Sevilla: De Robertis 1546; USTC 342635) the name is typeset but split into three pieces of text ("Dō", "Silues dela sel", "ua."), aligned at $135^{\circ} 0^{\circ}$ and $225^{\circ}$ angles to coincide with a woodcut banner (see Fig. 4).

20 In general, cf. Clive Griffin, The Crombergers of Seville. The History of a Printing and Merchant Dynasty. Oxford 1988.

21 For textual aspects and editorial strategies in the Cifar itself, see Juan Pablo Mauricio García Álvarez, 'Procedimientos textuales de impresor en el Libro del caballero Zifar (Cromberger, 1512): El caso de los epígrafes’. In: Zifar y sus libros. 500 años. Ed. by Karla Xiomara Luna Mariscal, Axayácatl Campos García Rojas and Aurelio González. México 2015, p. 265-308; and Juan Manuel Cacho Blecua, 'El género del 'Cifar' (Sevilla, Cromberger, 1512)'. In: Thesaurus LIV/1 (1999), p. 76-105.

22 Griffin (see note 20), p. 185 mentions that his microfiche-appendix "contains approximately 1,500 examples of woodcuts and decorative blocks used by the Cromberger press at Seville, but nevertheless does not represent all the blocks used in Cromberger editions." 


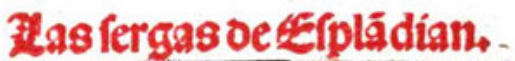

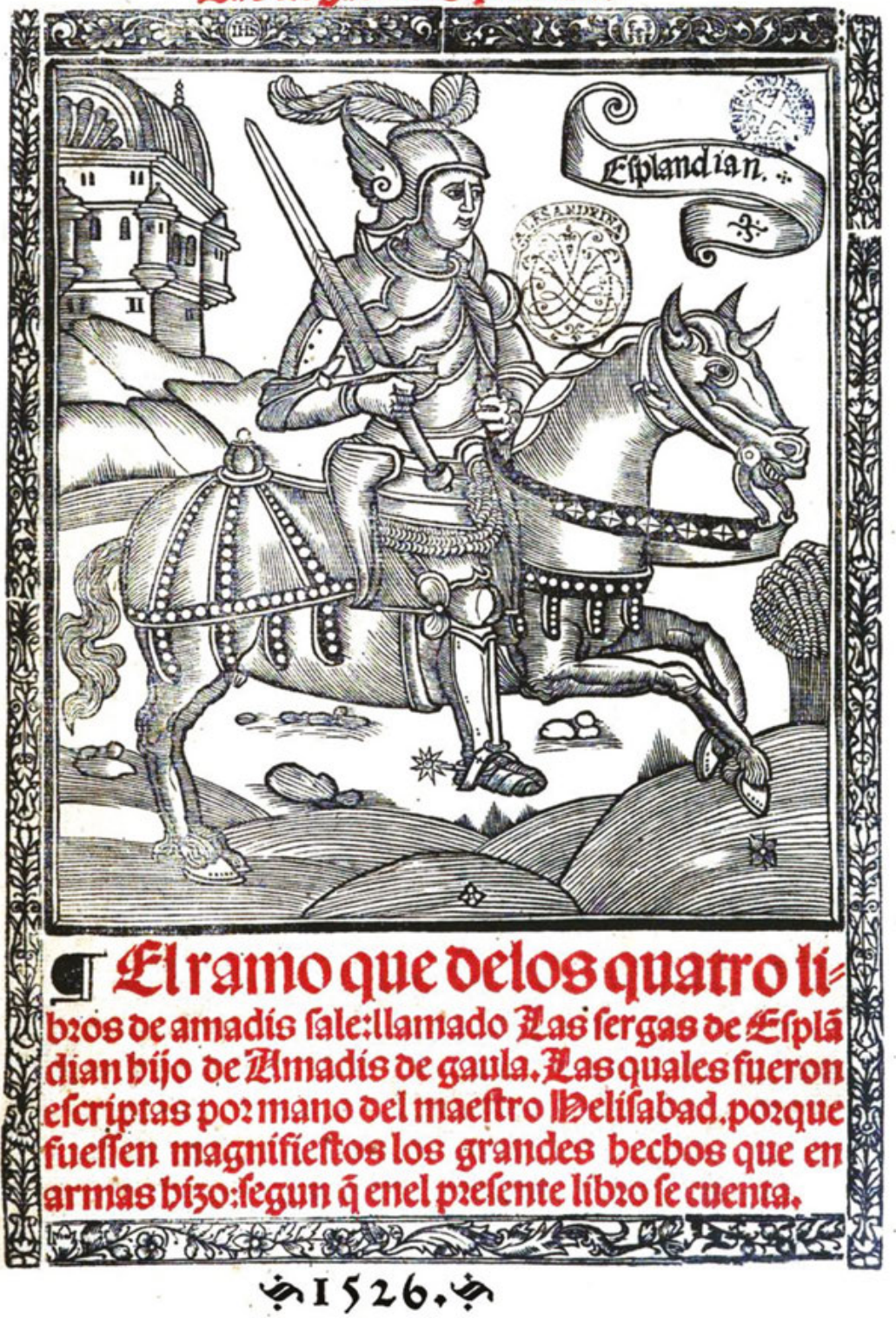

Fig. 1: Las Sergas de Esplandián (Burgos 1526). Biblioteca de Catalunya Bon. 8-III-17: title-page. 


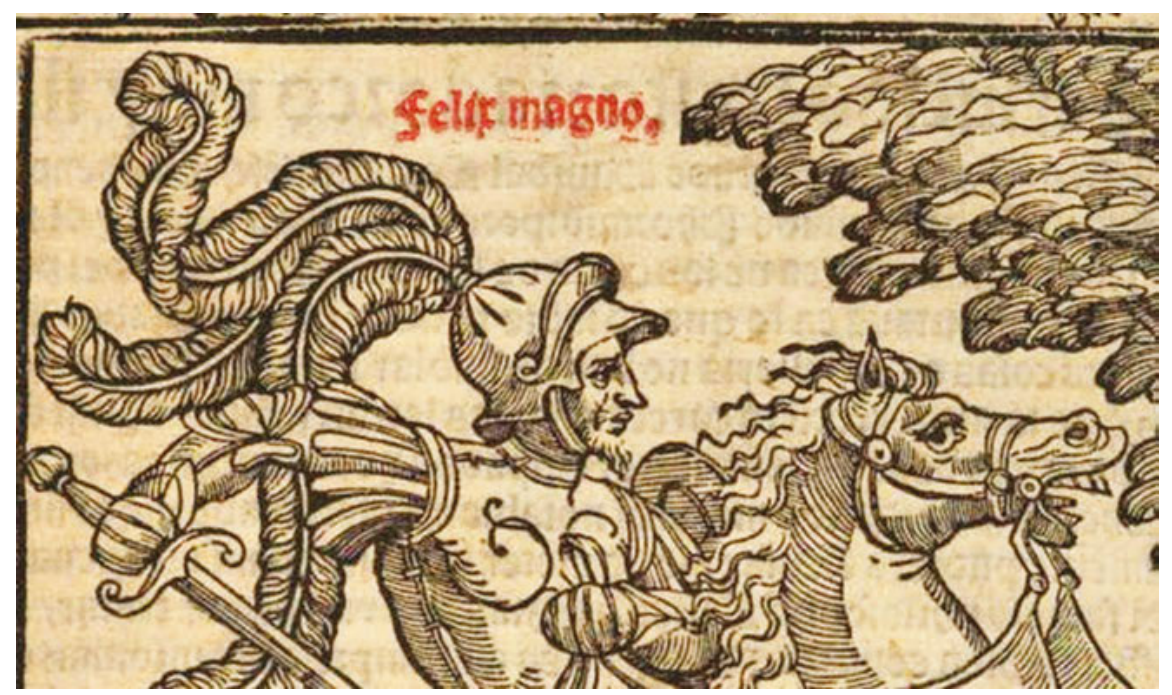

Fig. 2: Félix Magno (Sevilla 1549). Biblioteca de Catalunya Bon. 9-III-8: detail.

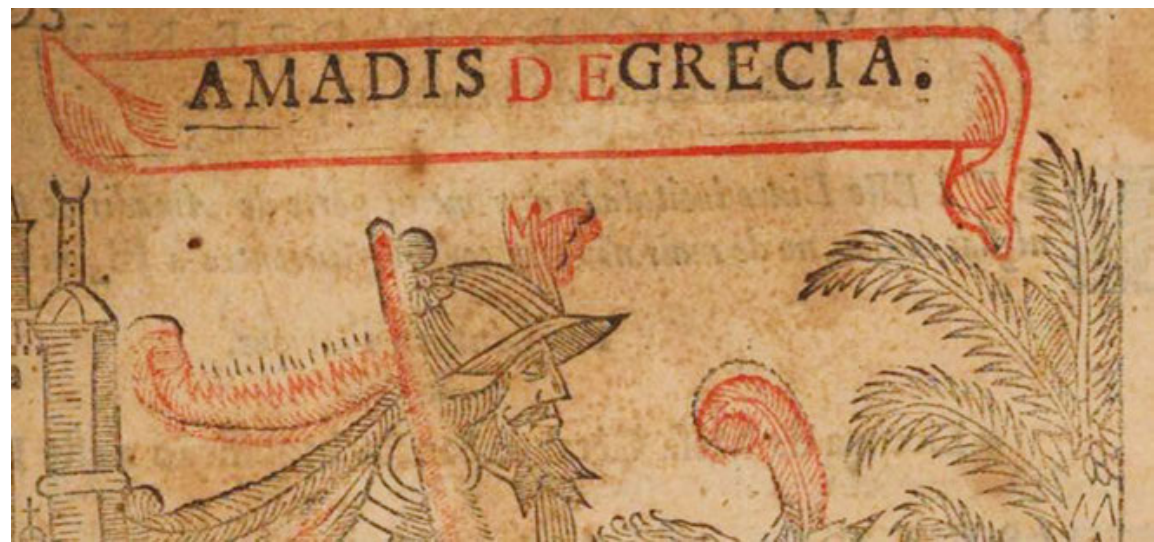

Fig. 3: Amadís de Grecia (Lisbon 1596). Österreichische Nationalbibliothek 40.R.33/9: detail.

Juan Cromberger, 1540; not in USTC) and it serves again as an illustration on fol. 66v of Jácome Cromberger’s 1545 Cirongilio de Tracia (USTC 342231). More interestingly, however, it was also used at the beginning of book four in Cromberger's 


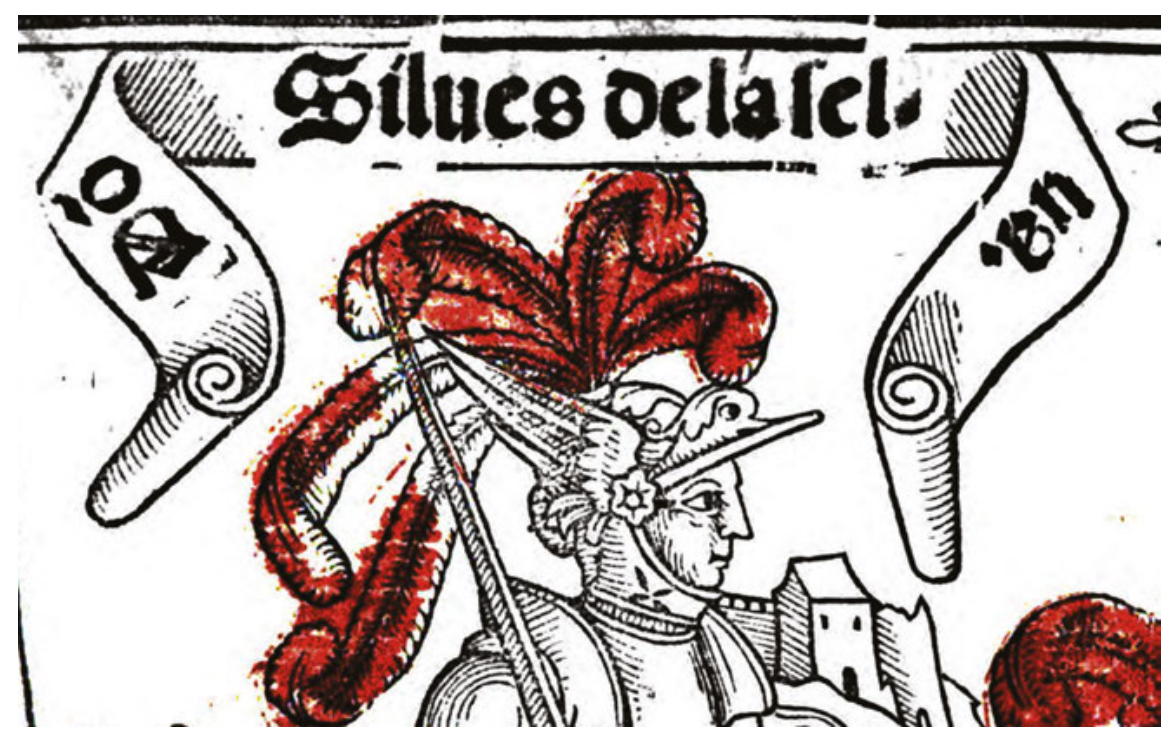

Fig. 4: Silves de la Selva (Sevilla 1546). Biblioteca de Catalunya Bon. 9-III-22: detail.

1526 Amadís (USTC 344299), replacing an omitted passage of text (fol. 201v: see Fig. $7^{23}$ ). The title-page of this edition features the much more famous woodcut of Amadís, accompanied by another knight and two squires, which the Crombergers used for a number of volumes and editions of the whole cycle (see Fig. 5). ${ }^{24}$ But it is the reuse of the earlier image within the 1526 book that gives us a decisive hint why that particular woodcut may have been imitated in Rome in 1519. As indicated above, the Cifar was quickly printed to have a chivalric text available after the success of earlier romances. Is very likely, therefore, that the image on its title-page had already been used before, specifically for the lost 1511 Amadis of Sevilla,

23 Together with an additional small woodcut on fol. 202r, it takes the place of Garci Rodríguez de Montalvo's prólogo to book four of Amadís, as is pointed out by Rafael Ramos, 'Problemas de la edición zaragozana del Amadís de Gaula (1508)'. In: Libros de caballerías (de “Amadís” al “Quijote"). Poética, lectura, representación e identidad. Ed. by Eva Belén Carro Carbajal, Laura Puerto Moro and María Sánchez Pérez. Salamanca 2002, p. 319-342, here p. 336 no. 17.

24 Parts of this woodcut were inspired by the image on the title-page of the 1521 Amadís (Zaragoza: Coci; USTC 348441), an illustration from an earlier edition of Titus Livius (Zaragoza: Coci 1520; USTC 337649). See Juan Manuel Cacho Blecua, 'Iconografía amadisiana: las imágenes de Jorge Coci’. In: eHumanista 16 (2010), p. 1-27, here p. 18-19. The argument centers on the unnatural body position of the walking horse in 1526, which corresponds to that of a standing horse in the 1521 Zaragoza Amadís. 


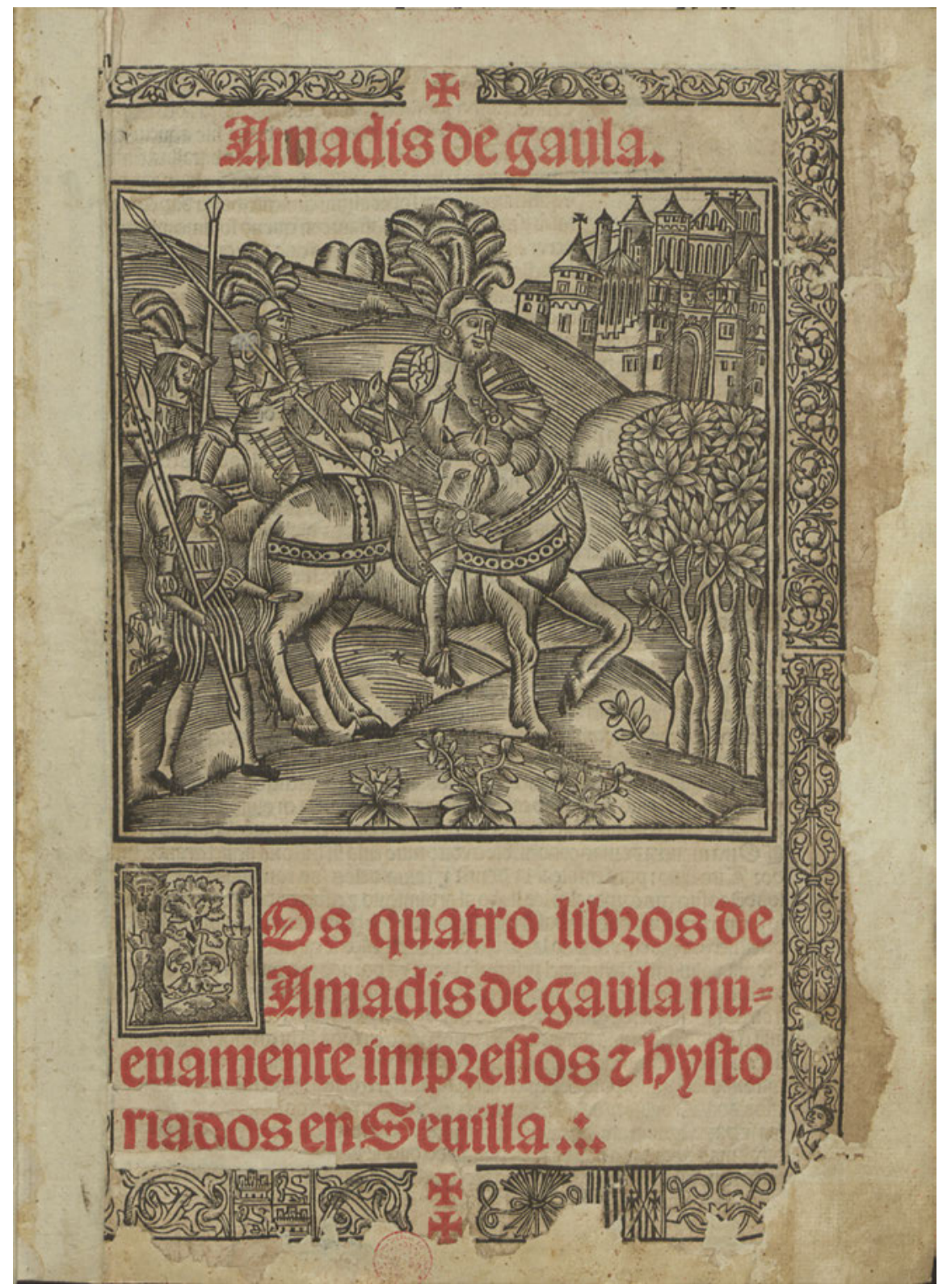

Fig. 5: Amadís de Gaula (Sevilla 1526) Biblioteca nacional de Portugal RES. 454 V: title-page. 

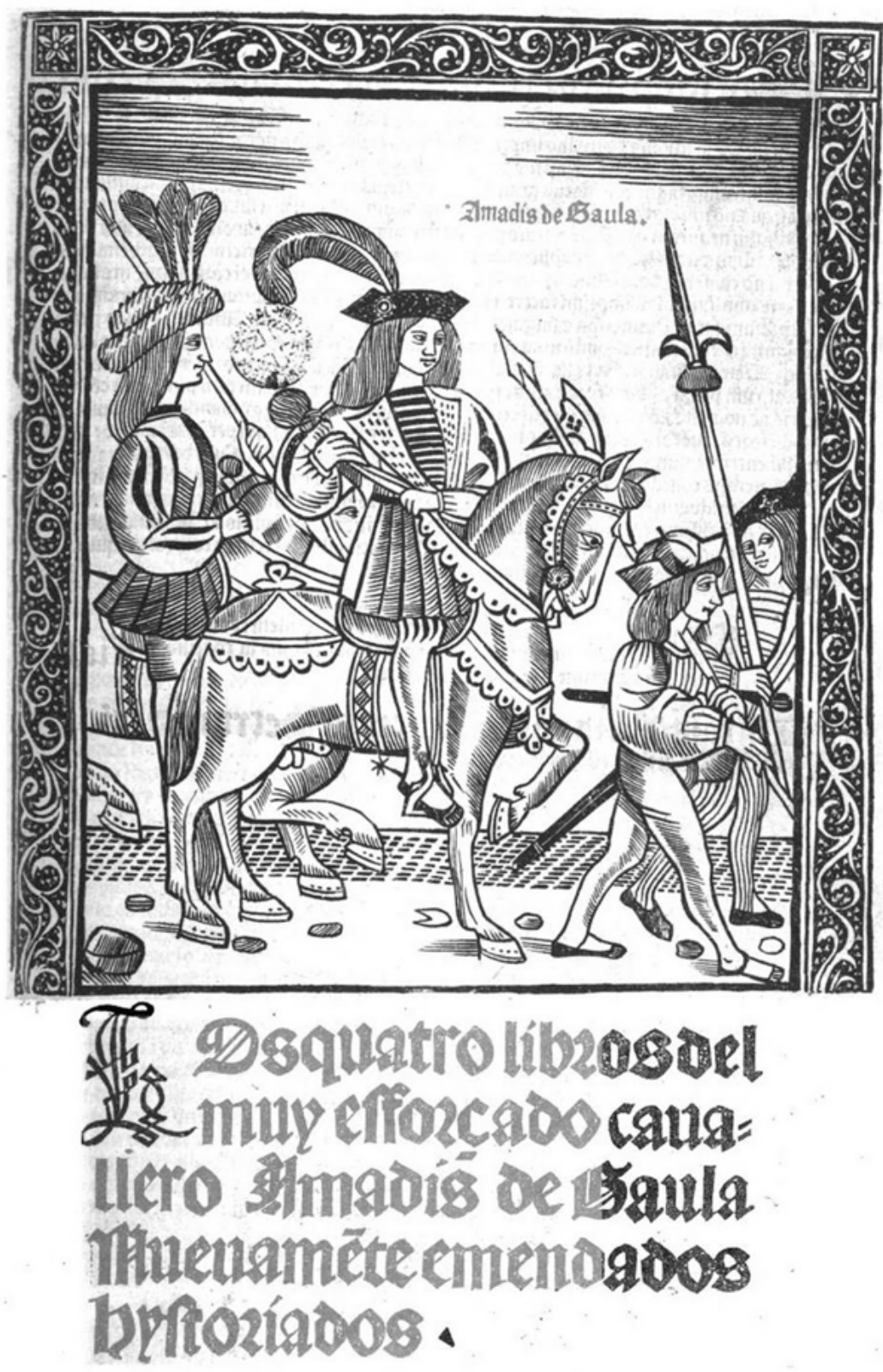

Fig. 6: Amadís de Gaula (Rome 1519). Biblioteca de Catalunya Bon. 8-IV-11: title-page. 


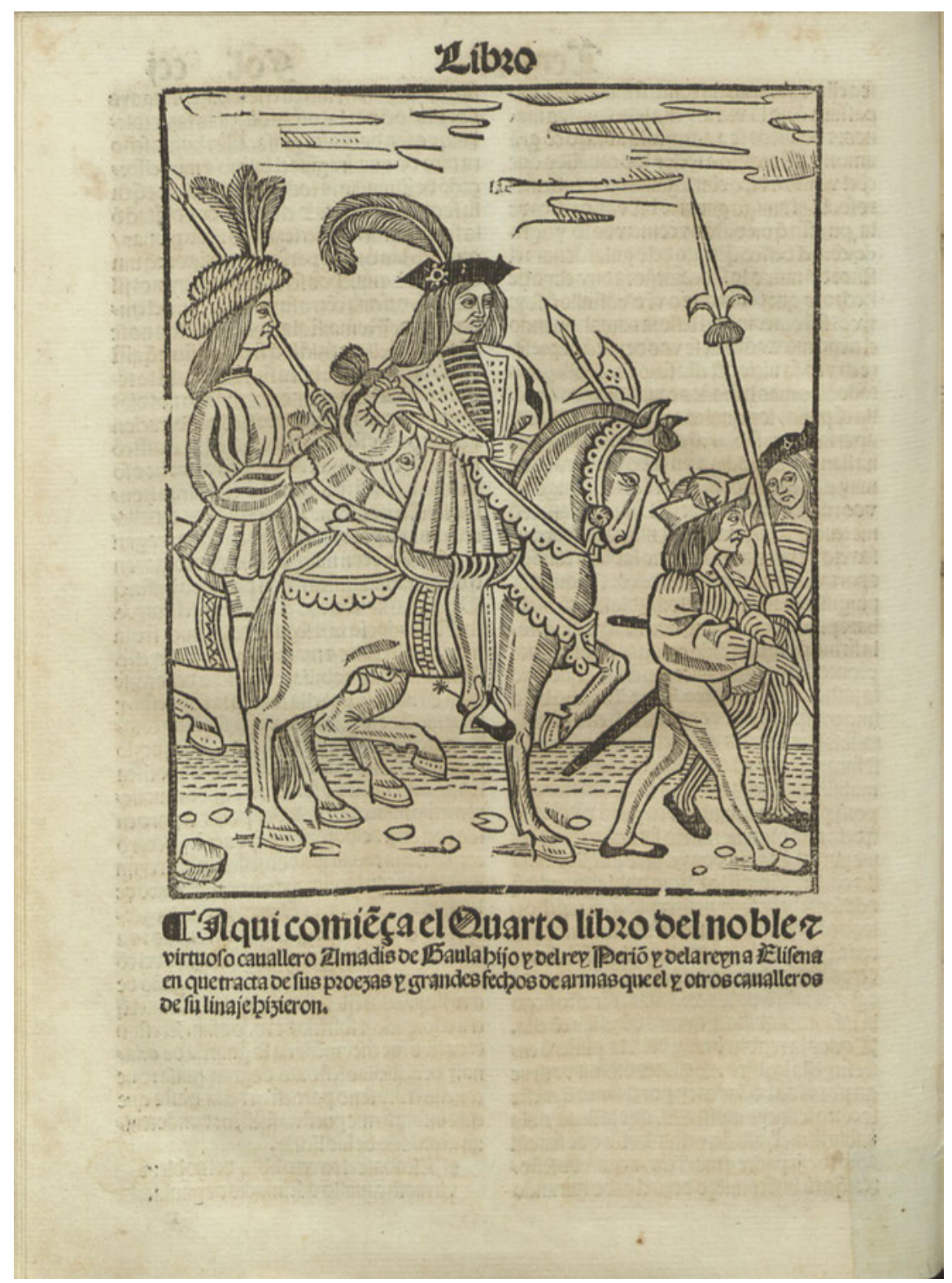

Fig. 7: Amadís de Gaula (Sevilla 1526) Biblioteca nacional de Portugal RES. 454 V: f. 201v. 
which is supposed to have been Cromberger's. This would not only explain why the printer once again adapted the image for the 1526 Amadis, but why it featured in the 1512 Cifar, as well: It made the medieval text look exactly like the biggest success so far of the new chivalric genre. It also makes perfect sense for the Roman edition to closely follow the look of Cromberger's 1511 Amadis, a connection underlined by the fact that many of the illustrative woodcuts in the 1519 edition look almost exactly like the illustrations in Cromberger's 1526 Amadis, in turn presumably modelled on the same printing house's earlier edition. ${ }^{25}$ Since the artistic quality of the Roman woodcuts, especially regarding facial expressions and other details, is considerably lower than that of Cromberger's 1526 edition, it is unlikely that they could have been the model for the latter. It is conceivable that both editions go back to an unknown, still earlier print, but it seems quite convincing that Amadis in 1511 looked very much like the 1519 imitation. Which is to say, very close to the 1526 edition, with the exception of the title-page and the prologue to book four. ${ }^{26}$

This clearly shows how certain design features of the romances were repeated over decades. By the early 1530s, the template had become part of the genre's tradition. This is especially striking when contrasted with the development of book design in general. ${ }^{27}$ In Spain, books of all genres had by and large followed a similar pattern to that of the romances around 1490-1515 (woodcut, red-and-black ink, long titles). A decade later, the situation is more complicated. Even though Spain lagged behind Europe in this respect, mostly for economic reasons, as Lucía Megías argues, there was a general shift toward a more modern title-page in roman type, with the year and place of impression. ${ }^{28}$

25 Importantly, the first known edition of Amadís (Zaragoza: Coci 1508; USTC 342622) did not have any illustrative woodcuts in the text, cf. Cacho Blecua, 'Iconografia amadisiana' (note 24), p. 8.

26 Similar conclusions were reached in a paper by Maria Cristina Misiti, but in a more hypothetical manner, because the author was unable to directly compare the two books and examined only Cromberger's 1531 Amadís (USTC 338329) where many illustrative woodcuts are actually different from those used in 1526. See Maria Cristina Misiti, 'Alcune rare edizioni spagnole pubblicate a Roma da Antonio Martínez de Salamanca'. In: El libro antiguo español. Actas del segundo Coloquio Internacional (Madrid). Ed. by María Luisa López-Vidriero and Pedro M. Cátedra. Salamanca 1992, p. 307-323; Lucía Megías, Imprenta y libros (note 16), p. 147-149. The question is raised again by Folke Gernert, 'Antonio Martínez de Salamanca, impresor y Francisco Delicado, corrector. Libros españoles en la imprenta italiana a través de sus ilustraciones'. In: Nápoles - Roma 1504. Cultura y literatura española y portuguesa en Italia en el quinto centenario de la muerte de Isabel la Católica. Ed. by Javier Gómez-Montero. Salamanca 2005, p. 205-242.

27 For the chronological development of title-pages, see Rautenberg (see note 9), p. 16.

28 Lucía Megías Imprenta y libros (note 16), p. 436-437. 
This affected the romances too, only more slowly. From this point on, their formal conservatism is most apparent by a comparison with the libros de caballerias printed outside of Spain. But while some features of the old-style design were long kept in place, presumably as a marker of genre, even they were adapted to a degree. From 1526 onwards, many editions feature a date on the title-page (and in many cases full information about printer and place, which was only legally required after 1558). The colophon was generally retained as well, but it served as much as a feature of the narration as for giving necessary details of the edition. Often printed before the tables of contents, in the case of a Leuven edition of Amadis from 1551 (USTC 440043) dividing the text into two quarto-volumes, there is only a 'colophon' at the end of volume two.

A more drastic change of the outward appearance of chivalric romances can, generally speaking, be observed only by the 1580s. At that time, the books still featured woodcuts of knights, but they tended to be placed like vignettes in the middle of the page. ${ }^{29}$ Most significantly, there is now an overall change from gothic to roman type for the romances, a trend that had begun about twenty years earlier. ${ }^{30}$

29 For instance Florisel de Niquea (Zaragoza: Domingo de Portonaris Ursino 1584; USTC 338102), two editions of the Sergas de Esplandian (Zaragoza: de Portonaris 1587 (colophon: 1586); USTC 342628; and Alcalá de Henares: hered. Juan Gracián 1588; USTC 345710); or the Chronica de [. . . Lisvarte de Grecia [. . .] Y de Perion de Gaula (Zaragoza: Puig, Escarilla 1587; USTC 337172). There is also a lone exception as early as 1551, the Libro segvndo, De la quarta y gran parte de la Choronica del excelente Principe don Florisel de Niquea (Salamanca: Andrea de Portonariis 1551; USTC 338314), for which, however, an alternative traditional title-page (albeit with roman lettering) exists, which is reproduced in José Manuel Lucía Megías (ed.), Amadis de Gaula 1508, quinientos años de libros de caballerías. Madrid 2008, p. 150.

30 The earliest cases known to me that keep the old title-page format of woodcut and long title but already use roman type for the whole book are two editions by Francisco del Canto in Medina del Campo: Libro del inuencible cauallero Primaleon (1563; USTC 338787) and El noueno libro de Amadis de Gaula [...] Amadis de Grecia (1564; USTC 348405). These are followed by Olivante de Laura, extant in one copy with a torn title-page (Barcelona: Bornat 1564; USTC 337972), La coronica delos muy valie[n]tes caualleros don Florisel de Niquea y el fuerte Anaxartes [...] (Lisbon: Borges 1566; USTC 342633) and La primera parte de la qvarta [. . . de [. . .] Don Florisel de Niquea (Zaragoza: Floresta 1568; USTC 337518), as well as the problematic 1551 Salamanca Florisel (mentioned in note 29). The practice of combining the old-style title-page with roman script is still in use much later, cf. Tercera y quarta parte del imbencible principe do[n] Belianis de Grecia [...] (Burgos: Pedro de Santillana 1579; USTC 336253) and Libro septimo de Amadis, enel qual se trata [n] los grandes hechos en armas de Lisuarte de Grecia [...] (Lisbon: Alonso Lopez 1587; USTC 344302). Unsurprisingly, there are several other anomalies: the Primera parte de la grande historia del [.. . ] principe Felixmarte de Yrcania (Valladolid: Francisco Fernandez de Cordoba 1556; USTC 340371) is set in gothic, but has roman type title-page, privileges and prologue (a second variant, the incomplete copy of the Biblioteca de Catalunya, Bon. 8-III-15, adds information on a fictitious 
Some printers, especially outside of Spain, never conformed to the familiar design. One Palmerin de Oliua (Venetia: Gregorio de Gregorijs, 1526; USTC 344509) did have an elaborate woodcut frame and a knight on horseback, but mixed roman and gothic type. Overall, it looked nothing like a typical chivalric romance. Another edition of the same text (Veneçia: Juan Paduan \& Venturin de Rufinelli, 1534; USTC 802676) is not set in columns and exists with two different title-pages, only one of which is ostensibly 'chivalric'. ${ }^{31}$ Finally, Los tres libros del muy efforçado cauallero Primaleon (Venecia: Nicolini de Sabio, 1534; USTC 337939) had a gothic title-page but was set in roman type without columns and with woodcut illustrations throughout. Even in Spain, though, there was at least one exception: The Espeio de principes y cavalleros (Zaragoza: Nagera 1555; not in USTC) is presented more than anything as a humanist text. Printed in roman script, it has a modern title-page with a printer's vignette surrounded by a large border, in the style of a three-dimensional frame complete with columns, statues, satyrs and a lion's head ("una orla complicada y clasicista"). ${ }^{32}$ This probably reflects the conscious attempt to renew certain aspects of the genre, as programmatically stated by its author, Diego Ortúnez de Calahorra, in a preface ${ }^{33}$ :

leyendo algunas desocupadas horas en estos libros, se recrea el animo, y se leuanta el coraçon, adelgazase el ingenio, auiua se el juyzio, despiertase el sentido. [...] Bien que no es mi intento de loar agora todo el requaje de libros de cauallerias que estan escriptos,

translation and the year 1557 onto the title-page, but retains 1556 in the colophon. See USTC 348325). One edition of Lepolemo (Toledo: Ferrer 1552/1553; USTC 346549) curiously uses roman type for the colophon only. The problem of gothic and roman types is extensively treated by Lucía Megías, Imprenta y libros (note 16), p. 433-447.

31 It is likely, however, that the chivalric woodcut does reflect a revision of the title-page in the common style of the genre (short title above; woodcut; long title below). A guess at the chronology is possible because the 'chivalric' title-page a) slightly revises the long title, from "nueuame[n]te restampado: y corregido: con su tabla" to "[. . . restampado y corregido [...]", b) aligns the two-color print much more carefully, and c) corrects a typographical error of the other variant, where the word "grandes" (in red ink) reads "zrandes", printed over by a black "g". While that error could theoretically be a result of the resetting, this seems unlikely.

32 See Daniel Eisenberg's Introducción a 'Espejo de Príncipes y cavalleros [El Cavallero del Febo]' de Diego Ortúñez de Calahorra (http://www.cervantesvirtual.com/nd/ark:/59851/ bmcjq193; accessed 25 May 2017).

33 Frank Willaert rightly remarked to me that the use of the word Espejo (mirror, Speculum) also emphasizes the humanist and didactic aspects. There is, however, a precedent: Espejo de caballerías, first published in Toledo in 1525, is a Spanish prose version of Boiardo's Orlando innamorato. The didactic dimension of libros de caballerias is in itself a complex question. See also Lucía Megías, Imprenta y lengua (note 16), p. 204. 
porque no es menos sino que hay algunos que no hay enellos alegoria ni moralidad alguna, de que el lector se pueda aprouechar [...]

(a few spare hours' reading of these books will relax the mind, lift the heart, ease the spirit, revive judgement and awaken the senses [...] Even so I do not intend to praise the whole drove of libros de caballerías, because there are certainly some that have no allegorical or moral dimension which the reader may profit from)

He adds, conveniently hiding behind the guise of a fictitious translation, that "[el] Espejo de Principes y caualleros [...] sera agradable en su lectura, tiene alguna moralidad que a bueltas delas historias no sera tan enojosa quanto prouechosa para el que lo leyere". ${ }^{34}$ The text became a huge success and by 1562, it was also sold with a more traditional-looking woodcut title-page. ${ }^{35}$

Despite this apparent homogeneity, it would ultimately be important to contrast both the conservative and innovative tendencies of the printers of libros de caballerias with the actual content and style of the texts. We know of a number of books throughout the sixteenth century that were 'advertised' as though they were chivalric romances. This applies to the medieval Historia del caballero Cifar which Cromberger reedited in Sevilla in 1512, as well as to the spiritual tale of the Libro intitulado Peregrinacion de la vida del ho[m]bre puesta en batalla debaxo... (Medina del Campo: Guillermo de Millis, 1552; USTC 340706) which was presented with the typical ingredients of a libro de caballerias: the gothic lettering, a knight's name ("Cauallero del Sol") over a woodcut of the knight on a horse surrounded by rich borders, while the actual text is a religious allegory. ${ }^{36}$ The differences can be large, as in the case of a spiritual tale, but for the understanding of the genre, even smaller narrative differences can be of importance. This includes different modes of narration, which are not always directly reflected in the editorial presentation of the books.

34 "The Espejo de Principes y caualleros is pleasant to read and has a moral dimension that, being part of the story, is not bothersome so much as profitable for the reader."

35 The title-page of the edition Zaragoza: Miguel de Guesa 1562 (USTC 346243) is reproduced in Lucía Megías, Imprenta y libros (note 16), p. 178; the edition Alcalá de Henares: Iuan Iñiguez de Lequerica 1580 (USTC 340401) has a similar design but is set in roman type. The printer of the first edition, Nagera (Nájera) was active only from c. 1550-1555, for details on him and his production, mostly books of lyric Romances, see Giovanni Caravaggi, 'Esteban Godines de Nájera y Juan Coloma’. In: Revista de poética medieval 28 (2014), p. 177-187.

36 See Emma Herrán Alonso, 'Las narraciones caballerescas espirituales'. In: Amadís de Gaula 1508. Quinientos años de libros de caballerías. Ed. by José Manuel Lucía Megías. Madrid 2008, p. 265-270. 


\section{Long and Short Titles and Their Relation to Entrelacement as a Narrative Technique}

One of the ways in which the current exclusive use of short titles for the romances obscures our view of the genre's complexities, is by reducing necessary information contained in the original titles. Many of the Spanish romances (excluding, significantly, most of Amadis) are in fact narrated in a particular style which constantly switches between different narrative strands (the technique usually called entrelacement). Clearly, several narrative strands require a number of heroes on an equivalent scale, to allow the writers to interrupt the narration at critical (and suspenseful) moments as often as possible. This is an aspect the long titles of the romances do reflect, because very often two or more names are mentioned. Moreover, at least 18 romances out of the overall 60 are now referred to by completely different names. Febo el Troyano was actually called Primera parte del Dechado y Remate de grandes Hazañas. .., a title that went on to name three heroes and heroines - Febo, Hispalián dela Vengança and Clariana - and referred to "many others" ("otros muchos"). Sometimes, the names of heroes explicitly referred to in the long titles are simply dropped today. The Demanda del sancto Grial also originally mentioned two knights, Lançarote and Galaz on the original title-page. And Silves de la Selva, apart from Silves, also mentioned the characters Esferamundi, Amadís de Astra, Fortunián and Astrapolo on its title-page. ${ }^{37}$ Similarly, the Segunda parte del Espejo de Principes y Caballeros explicitly named the Emperador Trabacio, Alphebo, Risocler, Claridiano, Claridiana, Poliphebo de Tinacria, Archisilora and "otros". The case of sequels is especially interesting, since it has a direct relevance for the audience's expectations. What we know now simply as Roselao de Grecia was presented as the Tercera parte de Espejo de cauallerias. On the 1550 title-page, Roselao was in fact only mentioned after another hero, don Roserín. Distinguishing between different sub-categories, in part identifiable by their titles, is obviously of great importance for reception processes, apart from narratological analyses.

37 We find similar schemes in Belianís de Grecia, parts III-IV (Belianís, Belfloran de Grecia); Cristalián de España (Cristalián, Luzescanio); Felixmarte de Hircania (Felixmarte, Florasán de Misia); Florisel de Niquea (Florisel, Anaxartes); Lisuarte de Grecia (Lisuarte, Perión de Gaula); Morgante (Morgante, Roldán, Renaldos); Oliveros de Castilla (Oliveros, Artus de Algarve); Palmerín de Inglaterra (Palmerín, Floriano del Desierto, Florendos); Philesbián de Candaria (Philesbián, Felinís); Primaleón (Primaleón, Polendos); Rogel de Grecia (= Florisel de Niquea, tercera parte) (Rogel, Agesilao). 
Yet, as we indicated earlier, the habit of referring to the romances by short titles dates back as far as the sixteenth century. In part, this has to do with convenience, omitting some of the blurb-like information contained in the long titles. $^{38}$ It may also have to do with the running titles that had to abbreviate titles for technical reasons. There is also another feature of the title-page that emphasizes this development. We find that by 1526 at the latest, what looks like short titles tend to be featured on most romances. Usually set in type just above the woodcut, a certain ambiguity remains, because the name of the hero might sometimes be intended to identify the knight in the image. The 1526 Amadis of Jacobo and Juan Cromberger (USTC 344299) states “Amadis de gaula” above the woodcut (as though it identified the knight) in the same size of type as "Los quatro libros de Amadis de gaula”, which is somewhat redundantly printed below. ${ }^{39}$ The evidence of the whole corpus suggests, however, that while this feature may have in part originated as a legend for the illustration, it soon became a signal for the buyer, a kind of short title distinct from the long one containing more information. Other examples from the same period have a similar scheme to that of Amadis yet cannot be interpreted as a legend for the illustration. The title-page of Historia del inuencible cauallero do[n] Polindo hijo del rey Paciano rey de Numidia [...] (Toledo: 1526; USTC 337928) says "Primer libro de don Polindo" topmost above the woodcut. El ramo que delos quatro libros de amadis sale: llamado Las sergas de Espla[n]dian hijo de Amadis de gaula [...] (Burgos: Juan de Junta, 1526; USTC 348400) has the phrase "Las sergas de Espla[n]dian" in the same place (see Fig. 1). Both are, in terms of appearance and function, short titles. Moreover, the latter's title-page contains the name "Esplandian" on a banner inside the woodcut as well. This short title also allowed the printers to emphasize the fact that some romances belong to a cycle, as with another edition of the Sergas. Above the woodcut of Las sergas del muy efforçado \& inuencible cauallero Espla[n]dian hijo de Amadis de gaula (Sevilla: Juan Varela de Salamanca, 1526; USTC 348330), we find the phrase "Quinto libro de Amadis". ${ }^{40}$ All in all, we can distinguish an interesting functional

38 Some systematic thoughts on how titles act as blurbs informing the reader about the contents of the books are offered by Lucía Megías, Imprenta y libros (note 16), p. 258-276, but he does not consider the problem of various protagonists as a structural one (p. 273-275).

39 I have counted at least six of those ambiguous cases from 1546 to 1587.

40 A mixed form appears on another title-page (without a woodcut, but with a decorative border around the long title): Florisando. | Sexto libro de Amadis. [border] El qual trata delos | grandes \& hazaño= $\mid$ sos fechos d[e]l muy $\mid$ valie[n]te y efforca $=\mid$ do cauall[er]o Flori $\mid$ sando principe | de Ca[n]taria su | sobrino: fijo | d[e]l rey don | Floresta[n] de Cerdeña. (Sevilla: Juan Varela de Salamanca 1526; USTC 342630). 
development of the title-page, where a kind of short title is printed above the woodcut, with the long title below, but which is still in keeping with the traditional visual idiom and design template of the chivalric romances of ten or fifteen years earlier. ${ }^{41}$ Since both the long titles and this particular variant of short title tells us a lot about the way the books were presented to their readers, they need to be considered as crucial information about the individual volumes.

\section{The Title of Don Quixote}

The problem of original titles and their current misrepresentations even reappears when we turn to what is usually perceived as the end point of the chivalric tradition in Spain: Don Quixote. In many ways, Cervantes's novel departs from the design (as well as the content) of the earlier libros de caballerias. ${ }^{42}$ It is of course not set in gothic type, which by 1605 would have been unlikely for any romance, and only one early edition (Lisbon: Rodríguez 1605) divides the text into columns, in general unnecessary for the quarto format. The title-page of the princeps neither includes a chivalric-themed woodcut (instead there is a printer's vignette $)^{43}$; and while the proper name "Quixote" is divided in two ("Qvi- | xote") and thus supposedly de-emphasized, as was the case with many earlier romances, ${ }^{44}$ some scholars have suggested that this facilitates a pun. ${ }^{45}$

41 Indeed, some earlier romances feature the phrase "Con priuilegio" in the same spot above the woodcut: Arderique (Valencia: Juan Viñao 1517; USTC 344387), Clarián de Landanís (Toledo: Juan de Villaquiran 1518; USTC 344400) and Claribalte (Valencia: Juan Viñao 1519; USTC 336204). I have only found a single later example for this, Valerián de Ungria (Valencia: Francisco Díaz Romano 1540; USTC 336843).

42 The title-pages of Don Quixote are easily accessible in Manuel Henrich (ed.), Iconografía de las Ediciones del Quijote de Miguel de Cervantes Saavedra. Reproducción en facsímile de las portadas de 611 ediciones con notas bibliográficas. Valladolid 2005 [Barcelona 1905]. It served as the basis for most of the information in this section.

43 There are, however, knights pictured on the title-pages of three early editions: Lisboa: Rodríguez 1605; Lisboa: Crasbeeck 1605; Valencia: Mey 1605.

44 Of 120 examined title-pages, just under $40 \%$ have the name of the hero or heroes divided over two lines or otherwise abbreviated, e.g. "dō tri | stan de leonis"; "Pri- | maleō"; "reynaldos de mō | taluan".

45 See Emilo Torné, 'Arquitectura tipográfica del libro en el Siglo de Oro'. In: Imprenta, libros y lectura en la España del Quijote. Ed. by José Manuel Lucía Megías. Madrid 2006, p. 243-273, here p. 268. Torné quotes a paper by Augustin Redondo suggesting that "xote" on its own was equivalent to idiot, “tonto"; Redondo's article is now entitled 'De la portada al prólogo en el Quijote de 1605. Un problema de recepción' and is included in Augustin Redondo, En busca del Quijote desde otra orilla. Alcalá de Henares 2011, p. 17-40, here p. 24. 
No matter which position one takes in the debate on whether Don Quixote is a genuine chivalric romance, there can be no doubt that its title is important for the reception of the novel. ${ }^{46}$ As one of the most famous books in history, one does not expect to find any oversights in its publishing history, yet no recent edition known to me informs the reader about a very common alternative title of the novel. While all the early editions invariably have El ingenioso hidalgo [or: caballero, from the title of the 1615 second volume] don Quixote de la Mancha, in the second half of the seventeenth century, starting with a Brussels edition (Bruselas: Juan Mommarte, 1662), we suddenly find the title changed to Vida y hechos del ingenioso cavallero don Quixote de la Mancha. Moreover, this particular phrasing soon travelled back to Spain: In fact, from 1671 onwards (Bruselas: Pedro de la Calle, 1671), all known editions ${ }^{47}$ exclusively feature this phrasing until the edition of the Real Academia Española in 1780 restored the original title. Most nineteenth-century editions then followed this lead, with a few exceptions (Madrid 1782; 1808; 1840; Barcelona 1841; 1845-1846). ${ }^{48}$ Not to take into account this alternative title is a glaring omission, especially because of the way the text's interpretation shifted from ridicule to sublimity toward the end of the eighteenth century. ${ }^{49}$ Once again, the title could significantly guide the way a text is read: In Spanish literature, the phrase Vidas y Hechos (Life and Deeds) is mainly associated with the lives of kings and saints, even with Jesus Christ. ${ }^{50}$ As the exclusive title over a long period of Don Quixote's transmission, the phrase must have influenced the interpretation of

46 I follow Lucía Megás and Sales Dasí (see note 1) in counting Don Quixote among the genuine libros de caballerías. Cf. also Daniel Syrovy, Tilting at Tradition. Problems of Genre in the Novels of Miguel de Cervantes and Charles Sorel. New York, Amsterdam 2013.

47 Antwerp 1673; Madrid 1674; an edition without place or date, reprinted by Henrich (see note 39) as \# 25*; Antwerp 1697 (twice); Barcelona 1704; Madrid 1706; Madrid 1714; Antwerp 1719; Madrid 1723; Madrid 1730; Madrid 1735; Lyon 1736; London 1738; Madrid 1741; The Hague 1744; Madrid 1750 (twice); Madrid 1751; Barcelona 1755?; Amsterdam/Leipzig 1755; Tarragona 1757; Barcelona 1762; Madrid 1764; Madrid 1765 (twice); Antwerp 1770; Madrid 1771; Madrid 1777 (twice).

48 Cayuela (see note 2), talking about the "fluctuations des titres" of Spanish 17th century narratives, does say that "le Quichotte voit son titre modifié pour une edition flamande de 1662 " (p. 264), but the reference to only "one Flemish edition" is evidently misleading.

49 Cf. Anthony Close, The Romantic Approach to 'Don Quixote'. A Critical History of the Romantic Tradition in 'Quixote' Criticism. Cambridge 1978.

50 Compare Historia de la vida y hechos del imperador Carlos V. (Barcelona: s.n. 1560?; USTC 350861); Antonio de Fuenmayor's Vida y hechos de Pio V pontifice Romano (Madrid: Luis Sánchez 1595; USTC 336370); and most importantly the Flos sanctorum y historia general de la vida y hechos de Jesu Christo (Zaragoza: Domingo de Portonariis 1580; USTC 342411; and at least twelve more editions before 1600). 
the story of the mad hidalgo as that of a suffering, saint-like figure. Even apart from these questions of interpretation, the problem is fundamental for the transmission and reception of the novel. The complete omission of any reference to its alternative title in the common editions of Don Quixote will leave scholars at a loss to explain, for example, why Ludwig Tieck's 1799-1801 translation into German was printed as Leben und Thaten des scharfsinnigen Edlen Don Quixote von la Mancha (Berlin: Unger, 1799-1801, 4 vols.). That a general awareness of different historical titles is lacking even for a novel as popular and well-studied as Don Quixote, should make it obvious how much research there is still to be done in this respect.

\section{Bibliography}

Cacho Blecua, Juan Manuel, 'El género del 'Cifar' (Sevilla, Cromberger, 1512)'. In: Thesaurus LIV/1 (1999), p. 76-105.

Cacho Blecua, Juan Manuel, 'Iconografía amadisiana: las imágenes de Jorge Coci’. In: eHumanista 16 (2010), p. 1-27.

Canova, Andrea, 'Introduction'. In: Matteo Maria Boiardo, Orlando innamorato. L'inamoramento de Orlando. Ed. by Andrea Canova. Milano 2011, p. 5-65.

Caravaggi, Giovanni, ‘Esteban Godines de Nájera y Juan Coloma’. In: Revista de poética medieval 28 (2014), p. 177-187.

Cayuela, Anne, Le paratexte au siècle d'or. Prose romanesque, livres et lecteurs en Espagne au XVII siècle. Genève 1996.

Cervantes, Miguel de, El Ingenioso Hidalgo Don Quijote de la Mancha. Ed. by John Jay Allen. Madrid 2001.

Close, Anthony, The Romantic Approach to 'Don Quixote'. A Critical History of the Romantic Tradition in 'Quixote' Criticism. Cambridge 1978.

Eisenberg, Daniel and María Carmen Marín Pina, Bibliografía de los libros de caballerías castellanos. Zaragoza 2000 (digital edition: http://www.cervantesvirtual.com/obra/bib liografia-de-los-libros-de-caballeria-castellanos/).

Eisenberg, Daniel, Introducción a 'Espejo de Príncipes y cavalleros [El Cavallero del Febo]' de Diego Ortúñez de Calahorra (http://www.cervantesvirtual.com/nd/ark:/59851/bmcjq193; accessed 25 May 2017).

García Álvarez, Juan Pablo Mauricio, ‘Procedimientos textuales de impresor en el Libro del caballero Zifar (Cromberger, 1512): El caso de los epígrafes'. In: Zifar y sus libros. 500 años. Ed. by Karla Xiomara Luna Mariscal, Axayácatl Campos García Rojas and Aurelio González. México 2015, p. 265-308.

Gernert, Folke, 'Antonio Martínez de Salamanca, impresor y Francisco Delicado, corrector. Libros españoles en la imprenta italiana a través de sus ilustraciones'. In: Nápoles Roma 1504. Cultura y literatura española y portuguesa en Italia en el quinto centenario de la muerte de Isabel la Católica. Ed. by Javier Gómez-Montero. Salamanca 2005, p. 205-242. 
Griffin, Clive, The Crombergers of Seville. The History of a Printing and Merchant Dynasty. Oxford 1988.

Henrich, Manuel (ed.), Iconografía de las Ediciones del Quijote de Miguel de Cervantes Saavedra. Reproducción en facsímile de las portadas de 611 ediciones con notas bibliográficas. Valladolid 2005 [Barcelona 1905].

Herrán Alonso, Emma, 'Las narraciones caballerescas espirituales'. In: Amadís de Gaula 1508. Quinientos años de libros de caballerías. Ed. by José Manuel Lucía Megías. Madrid 2008, p. 265-270.

López-Vázquez, Alfredo Rodriguez (ed.), Segunda parte del Lazarillo de Tormes. Madrid 2014. Lucía Megías, José Manuel and Emilio José Sales Dasí, Libros de caballerías castellanos (siglos XVI-XVII). Madrid 2008.

Lucía Megías, José Manuel, Imprenta y libros de caballerías. Madrid 2000.

Lucía Megías, José Manuel, 'Imprenta y lengua literaria en los Siglos de Oro: el caso de los libros de caballerías castellanos.' In: Edad de Oro 23 (2004), p. 199-229.

Lucía Megías, José Manuel (ed.), Amadis de Gaula 1508, quinientos años de libros de caballerías. Madrid 2008.

Misiti, Maria Cristina, 'Alcune rare edizioni spagnole pubblicate a Roma da Antonio Martínez de Salamanca’. In: El libro antiguo español. Actas del segundo Coloquio Internacional (Madrid). Ed. by María Luisa López-Vidriero and Pedro M. Cátedra. Salamanca 1992, p.307-323.

Moretti, Franco, Distant Reading. London, New York 2013.

Oliver, Revilo P., 'The First Medicean MS of Tacitus and the Titulature of Ancient Books'. In: Transactions and Proceedings of the American Philological Association 82 (1951), p. 232-261.

Ramos, Rafael, 'Problemas de la edición zaragozana del Amadís de Gaula (1508)'. In: Libros de caballerías (de "Amadís" al "Quijote"). Poética, lectura, representación e identidad. Ed. by Eva Belén Carro Carbajal, Laura Puerto Moro and María Sánchez Pérez. Salamanca 2002, p. 319-342.

Rautenberg, Ursula, 'Die Entstehung und Entwicklung des Buchtitelblatts in der Inkunabelzeit'. In: Archiv für Geschichte des Buchwesens 62 (2008), p. 1-105.

Redondo, Augustin, 'De la portada al prólogo en el Quijote de 1605. Un problema de recepción'. In: A.R., En busca del Quijote desde otra orilla. Alcalá de Henares 2011, p. $17-40$.

Sánchez Mariana, Manuel, 'La novela en manuscrito en los Siglos de Oro'. In: Imprenta, libros y lectura en la España del Quijote. Ed. by J. M. Lucía Megías. Madrid 2006, p. 119-138.

Sarmati, Elisabetta, Le critiche ai libri di cavalleria nel cinquecento spagnolo (con uno sguardo sul seicento). Un'analisi testuale. Pisa 1996.

Sharpe, Richard, Titulus. Identifying Medieval Latin Texts. Turnhout 2006.

Syrovy, Daniel, Tilting at Tradition. Problems of Genre in the Novels of Miguel de Cervantes and Charles Sorel. New York, Amsterdam 2013.

Torné, Emilo, ‘Arquitectura tipográfica del libro en el Siglo de Oro’. In: Imprenta, libros y lectura en la España del Quijote. Ed. by José Manuel Lucía Megías. Madrid 2006, p. 243-273.

Wilkinson, Alexander S. (ed.), Iberian Books. Leiden, Boston 2010. 